\title{
Magnesium and nickel(II) furan-2,5-dicarboxylate
}

\section{Schau-Magnussen, Magnus; Gorbanev, Yury; Kegnæs, Søren; Riisager, Anders}

\section{Published in:}

Acta Crystallographica. Section C: Crystal Structure Communications

Link to article, DOI:

$10.1107 /$ S0108270111036535

Publication date:

2011

Document Version

Publisher's PDF, also known as Version of record

Link back to DTU Orbit

Citation (APA):

Schau-Magnussen, M., Gorbanev, Y., Kegnæs, S., \& Riisager, A. (2011). Magnesium and nickel(II) furan-2,5dicarboxylate. Acta Crystallographica. Section C: Crystal Structure Communications, 67, M327-M330. https://doi.org/10.1107/S0108270111036535

\section{General rights}

Copyright and moral rights for the publications made accessible in the public portal are retained by the authors and/or other copyright owners and it is a condition of accessing publications that users recognise and abide by the legal requirements associated with these rights.

- Users may download and print one copy of any publication from the public portal for the purpose of private study or research.

- You may not further distribute the material or use it for any profit-making activity or commercial gain

- You may freely distribute the URL identifying the publication in the public portal 
Acta Crystallographica Section C

\section{Crystal Structure}

Communications

ISSN 0108-2701

\section{Magnesium and nickel(II) furan-2,5- dicarboxylate}

\author{
Magnus Schau-Magnussen, ${ }^{\mathrm{a} *}$ Yury Y. Gorbanev, ${ }^{\mathrm{b}}$ Søren \\ Kegnæs $^{b}$ and Anders Riisager ${ }^{b}$
}

${ }^{a}$ Department of Chemistry, University of Copenhagen, Universitetsparken 5, DK-2100 Copenhagen, Denmark, and ${ }^{\mathbf{b}}$ Department of Chemistry, Centre for Catalysis and Sustainable Chemistry, Technical University of Denmark, Building 207, DK-2800 Kgs. Lyngby, Denmark

Correspondence e-mail: magnus@kiku.dk

\section{Received 5 July 2011}

Accepted 7 September 2011

Online 17 September 2011

The salts hexaaquamagnesium furan-2,5-dicarboxylate, [Mg$\left.\left(\mathrm{H}_{2} \mathrm{O}\right)_{6}\right]\left(\mathrm{C}_{6} \mathrm{H}_{2} \mathrm{O}_{5}\right)$, (I), and hexaaquanickel furan-2,5-dicarboxylate, $\left[\mathrm{Ni}\left(\mathrm{H}_{2} \mathrm{O}\right)_{6}\right]\left(\mathrm{C}_{6} \mathrm{H}_{2} \mathrm{O}_{5}\right)$, (II), provide the first crystallographic characterization of the furan-2,5-dicarboxylate dianion. Both structures exhibit extensive three-dimensional hydrogen-bonding networks between the octahedral coordinated hexaaquametal(II) ions and the dicarboxylate anions. Although the two structures are not isomorphous, they contain essentially identical two-dimensional slabs. The distinction between the structures is that these slabs are related by translation in (II), whereas adjacent slabs in (I) are reflected relative to each other by the action of a glide plane. The reflection occurs so that the local contacts between slabs are not changed, and thus the hydrogen-bond networks are identical except for the orientation of the water molecules at the interface between slabs.

\section{Comment}

Furan-2,5-dicarboxylic acid (FDA) has been identified by the US Department of Energy biomass programme as one of the 12 chemicals that in the future can be used as a feedstock from biomass in biorefineries (Werpy \& Petersen, 2004; Bozell \& Petersen, 2010). Owing to the presence of the two carboxylic acid groups, FDA is considered to be a biorenewable building block in the formation of polymers from biomass and therefore may become an alternative to terephthalic, isophthalic and adipic acids, which are all produced from fossil fuel resources (Bozell \& Petersen, 2010; Boisen et al., 2009; Gorbanev et al., 2011). In order to be able to use FDA as a building block for polymers, the compound must be of high purity. Herein we show that it is possible to crystallize furan2,5-dicarboxylate as magnesium and nickel salts starting from FDA and the metal carbonates in water.

The title compounds, hexaaquamagnesium furan-2,5-dicarboxylate, (I), and hexaaquanickel furan-2,5-dicarboxylate,
(II), have the same molecular structure and the crystals are constitutionally identical. The asymmetric unit comprises one $\left[M\left(\mathrm{H}_{2} \mathrm{O}\right)_{6}\right]^{2+}$ cation and one furan-2,5-dicarboxylate anion. The $\mathrm{Mg}$ and $\mathrm{Ni}$ structures are illustrated in Figs. 1 and 2, respectively. The metal-water distances in the cations, as well

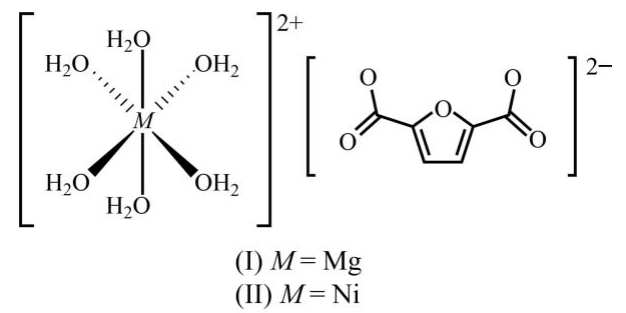

as the bond lengths in the dianions, are unexceptional. With $\mathrm{Mg} 1-\mathrm{O}$ (water) bond lengths of 2.0289 (7)-2.1077 (7) $\AA$ and $\mathrm{Ni1}-\mathrm{O}$ (water) bond lengths of $2.0219(5)-2.0840$ (6) $\AA$, all distances are approximately equal to the average bond lengths of previously characterized $\left[M\left(\mathrm{H}_{2} \mathrm{O}\right)_{6}\right]^{2+}$ complexes $[\mathrm{Mg}-\mathrm{O}=$ 2.06 (2) $\AA$ and $\mathrm{Ni}-\mathrm{O}=2.05$ (2) $\AA$ ] in the Cambridge Structural Database (CSD; Version 5.32 of November 2010; Allen,

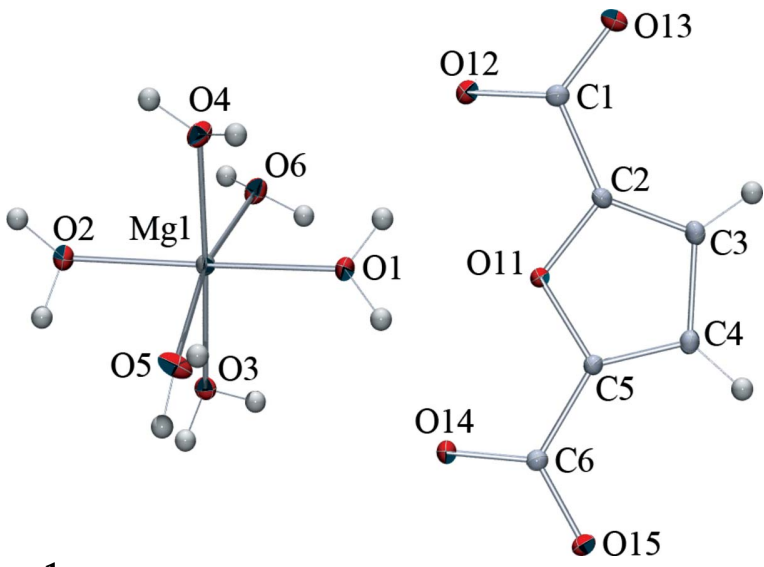

Figure 1

View of the molecular structure of (I), showing the atom-labelling scheme. Displacement ellipsoids are drawn at the $50 \%$ probability level and $\mathrm{H}$ atoms are shown as spheres of arbitrary radii.

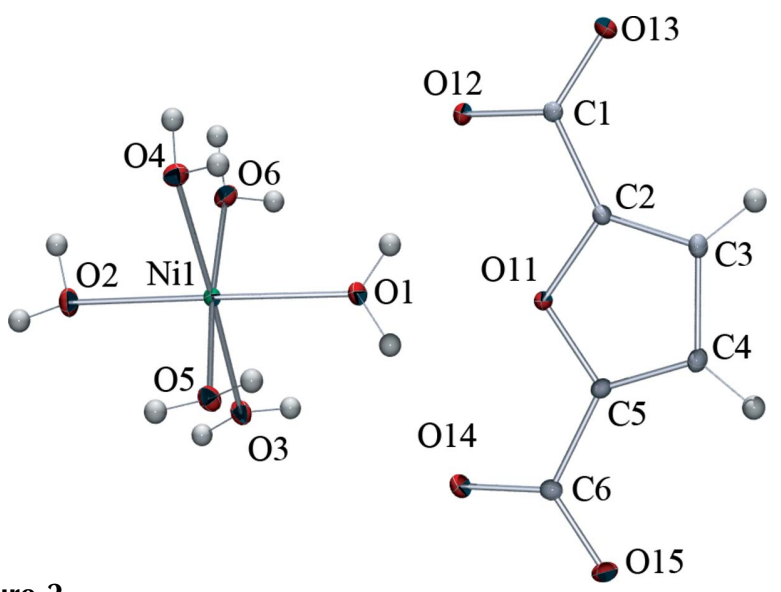

Figure 2

View of the molecular structure of (II), showing the atom-labelling scheme. Displacement ellipsoids are drawn at the $50 \%$ probability level and $\mathrm{H}$ atoms are shown as spheres of arbitrary radii. 


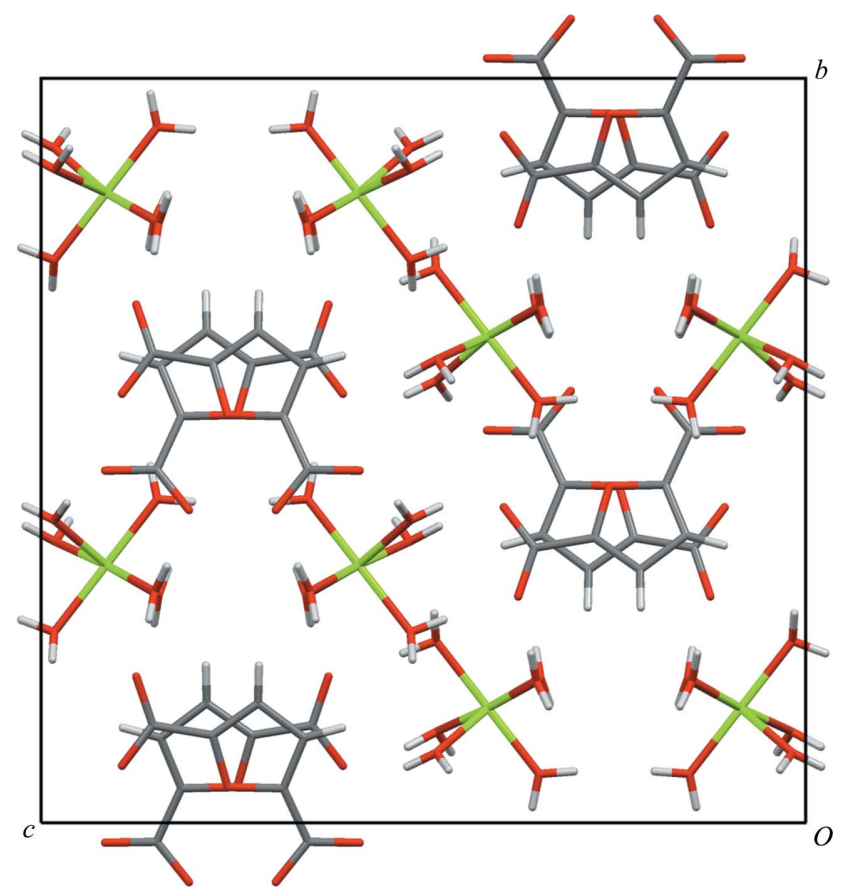

Figure 3

Packing diagram of (I), shown in projection along the $a$ axis. For clarity, the extensive hydrogen-bonding network is not shown.

2002). All bond lengths in the dianions are approximately equal to the bond lengths of the parent furan-2,5-dicarboxylic acid (Martuscelli \& Pedone, 1968) and also the monoanion in potassium catena-(2,5-dicarboxyfuran) (Jaulmes et al., 1982).

The intermolecular interactions are consequently the most interesting features of the structures. The packing in both (I) and (II) is governed by an elaborate three-dimensional hydrogen-bonding scheme. The presence of both an excellent hydrogen-bond donor (aqua ion) and acceptor (dicarboxylate) should lead to strong intermolecular interactions, and in both structures the packing allows short, almost linear, O$\mathrm{H} \cdot \mathrm{OO}$ hydrogen bonds (Tables 1 and 2), consistent with strong interactions (Jeffrey, 1997). It is also in the packing that the only significant distinction between the two structures becomes apparent. In (II), the planes of all of the furan-2,5dicarboxylate anions are parallel, whereas in (I) there exists two sets of anions where the molecular planes form an angle of $28.14(2)^{\circ}$ with each other.

Although the two compounds are not isomorphous, there is a very close relationship between them, which is expressed by the cell parameters: $c$ in (I) $[18.579(3) \AA] \simeq b$ in

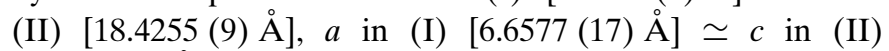
$[6.5942(8) \AA]$ and $\beta$ in (I) $=\alpha$ in (II) $=90^{\circ}$. Consequently, the structures contain almost identical two-dimensional slabs parallel to these specified unit-cell faces. The structures appear essentially identical in projection along the $a$ axis for (I) and along the $c$ axis for (II) (see Figs. 3 and 4). The crystallographic repeat unit of the two-dimensional slabs corresponds to the unit-cell contents of (II) (Fig. 4). In (II), adjacent slabs are related by direct translation along the $a$ axis. This gives rise to a monoclinic structure. In (I), the arrangement is such that the next slab is reflected compared to its neighbour (see Fig. 5), by

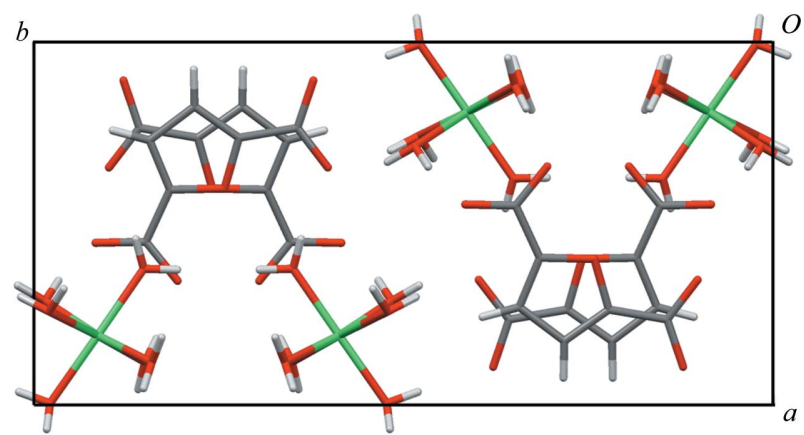

Figure 4

Packing diagram of (II), shown in projection along the $c$ axis. For clarity, the extensive hydrogen-bonding network is not shown.

virtue of the glide planes lying perpendicular to the $a$ axis. The reflection occurs between every slab so that the crystallographic translation encompasses two slabs and is perpendicular to the plane of the slabs. Thus, (I) is orthorhombic. The resulting relationship between the cell parameters in the two structures is: $b$ axis in (I) $\simeq[2 a \cos (\beta-90)]$ in (II).

The reflection of adjacent slabs in (I) occurs so that the local contacts between layers are not changed compared to those in (II), i.e. the positions of the atoms in contact between layers remain essentially unchanged. Thus, the hydrogen bonding between slabs is essentially identical in the two structures. The difference is the orientation of the water molecules at the interface between slabs.

This difference in structure for these two compounds with identical composition and comparable size of the metal ion is interesting but difficult to explain. The answer might be a subtle difference in the preferred geometry of the hexaaquametal(II) ions as a result of the different $d$-orbital configuration. The $d^{0}$-configuration of $\mathrm{Mg}^{2+}$ does not impose any energetic penalty on the orientation of the coordinated water ligands compared to nickel $\left(d^{8}\right)$, thus accommodating a packing which leads to a structure with higher symmetry.

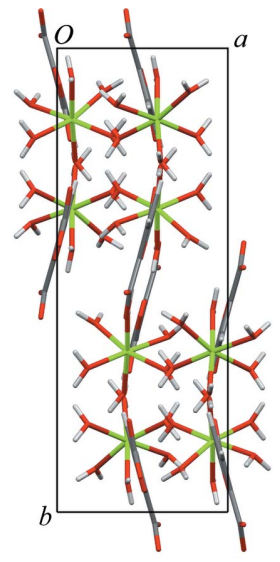

(I)

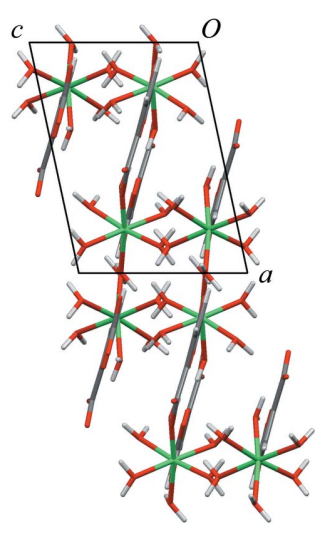

(II)
Figure 5

Packing diagrams of (I), in projection along the $c$ axis, and (II), in projection along the $b$ axis. In (I), the unit-cell repeat along the $b$ axis encompasses two slabs, while in (II) the unit-cell repeat along the $a$ axis encompasses only one slab. 


\section{Experimental}

The two title compounds were prepared by an adaptation of the reported synthesis of the related compound pentaaqua(furan-2-carboxylato)nickel(II) furan-2-carboxylate (Paluchowska et al., 1994). Furan-2,5-dicarboxylic acid was prepared as described previously (Gorbanev et al., 2009). The compound was recrystallized from warm water and precipitated with hydrochloric acid before use.

To a hot aqueous solution $(10 \mathrm{ml})$ of furan-2,5-dicarboxylic acid $(1 \mathrm{mmol}, 156 \mathrm{mg}$ ) was added the carbonate salt of magnesium or nickel $(1 \mathrm{mmol})$. The solutions were cooled to room temperature. Water was evaporated slowly at room temperature for a few days and colourless crystals of (I) or green crystals of (II) suitable for X-ray analysis were obtained. Elemental analysis found (calculated): for (I), C 24.27 (25.16), H 4.53\% (4.93\%); for (II), C 22.69 (22.46), H $4.30 \%$ $(4.40 \%)$

\section{Compound (I)}

\section{Crystal data}

$\left[\mathrm{Mg}\left(\mathrm{H}_{2} \mathrm{O}\right)_{6}\right]\left(\mathrm{C}_{6} \mathrm{H}_{2} \mathrm{O}_{5}\right)$
$M_{r}=286.48$
Orthorhombic, $P b c a$
$a=6.6577(17) \AA$
$b=18.1234(3) \AA$
$c=18.579(3) \AA$

$$
\begin{aligned}
& V=2241.8(6) \AA^{3} \\
& Z=8 \\
& \text { Mo } K \alpha \text { radiation } \\
& \mu=0.21 \mathrm{~mm}^{-1} \\
& T=122 \mathrm{~K} \\
& 0.31 \times 0.23 \times 0.07 \mathrm{~mm}
\end{aligned}
$$

\section{Data collection}

Nonius KappaCCD diffractometer Absorption correction: integration (Coppens, 1970)

$T_{\min }=0.936, T_{\max }=0.986$

\section{Refinement}

$R\left[F^{2}>2 \sigma\left(F^{2}\right)\right]=0.035$

$w R\left(F^{2}\right)=0.092$

$S=1.06$

5972 reflections

199 parameters

12 restraints

\section{Compound (II)}

\section{Crystal data}

$\left[\mathrm{Ni}\left(\mathrm{H}_{2} \mathrm{O}\right)_{6}\right]\left(\mathrm{C}_{6} \mathrm{H}_{2} \mathrm{O}_{5}\right)$
$M_{r}=320.88$
Monoclinic, $P 2_{1} / c$
$a=9.2242(5) \AA$
$b=18.4255(9) \AA$
$c=6.5942(8) \AA$
$\beta=102.066(6)^{\circ}$

\section{Data collection}

Nonius KappaCCD diffractometer Absorption correction: integration (Gaussian integration; Coppens, 1970)

$T_{\min }=0.505, T_{\max }=0.950$

\section{Refinement}

$R\left[F^{2}>2 \sigma\left(F^{2}\right)\right]=0.028$

$w R\left(F^{2}\right)=0.060$

$S=1.10$

9072 reflections

199 parameters

12 restraints

independent and constrained refinement

\begin{tabular}{|c|c|c|c|c|}
\hline$D-\mathrm{H} \cdots A$ & $D-\mathrm{H}$ & $\mathrm{H} \cdots A$ & $D \cdots A$ & $D-\mathrm{H} \cdots A$ \\
\hline $\mathrm{O} 1-\mathrm{H} 1 A \cdots \mathrm{O} 11$ & $0.836(11)$ & $2.280(13)$ & $2.7201(8)$ & $113.2(11)$ \\
\hline $\mathrm{O} 1-\mathrm{H} 1 B \cdots \mathrm{O} 12$ & $0.849(12)$ & $2.051(12)$ & $2.8978(9)$ & $175.0(12)$ \\
\hline $\mathrm{O} 1-\mathrm{H} 1 A \cdots \mathrm{O} 14$ & $0.836(11)$ & $1.961(12)$ & $2.7869(8)$ & $169.6(13)$ \\
\hline $\mathrm{O} 2-\mathrm{H} 2 A \cdots \mathrm{O} 15^{\mathrm{i}}$ & $0.855(11)$ & $1.908(11)$ & $2.7624(9)$ & 176.9 (13) \\
\hline $\mathrm{O} 2-\mathrm{H} 2 B \cdots \mathrm{O} 3^{\mathrm{ii}}$ & $0.860(11)$ & $2.128(12)$ & $2.9658(9)$ & 164.5 (12) \\
\hline $\mathrm{O} 3-\mathrm{H} 3 A \cdots \mathrm{O} 13^{\mathrm{iii}}$ & 0.832 (11) & $1.872(11)$ & $2.7011(9)$ & $173.8(13)$ \\
\hline $\mathrm{O} 3-\mathrm{H} 3 B \cdots \mathrm{O} 14^{\mathrm{i}}$ & $0.852(11)$ & $1.838(11)$ & $2.6756(9)$ & $167.3(13)$ \\
\hline $\mathrm{O} 4-\mathrm{H} 4 A \cdots \mathrm{O} 15^{\mathrm{iv}}$ & $0.839(11)$ & $1.884(11)$ & $2.7200(9)$ & 174.4 (13) \\
\hline $\mathrm{O} 4-\mathrm{H} 4 B \cdots \mathrm{O} 12^{\mathrm{v}}$ & $0.831(11)$ & $2.001(12)$ & $2.8267(9)$ & $172.4(13)$ \\
\hline $\mathrm{O} 5-\mathrm{H} 5 A \cdots \mathrm{O} 14^{\mathrm{i}}$ & $0.806(1$ & $2.205(12)$ & $2.8839(9)$ & $142.2(13)$ \\
\hline $\mathrm{O} 5-\mathrm{H} 5 B \cdots \mathrm{O} 13^{\mathrm{v}}$ & $0.845(12)$ & $1.906(12)$ & $2.7437(10)$ & 170.9 (14) \\
\hline $\mathrm{O} 6-\mathrm{H} 6 A \cdots \mathrm{O} 12^{\mathrm{iii}}$ & 0.819 (11) & 2.014 (11) & $2.8318(9)$ & 175.7 (13) \\
\hline $\mathrm{O} 6-\mathrm{H} 6 B \cdots \mathrm{O} 15^{\mathrm{vi}}$ & $0.826(11)$ & 2.005 (11) & $2.8096(9)$ & $164.5(12)$ \\
\hline
\end{tabular}

$\Delta \rho_{\max }=0.63$ e $\AA^{-3}$

$\Delta \rho_{\min }=-0.39{\mathrm{e} \AA^{-3}}^{-3}$

7619 reflections with $I>2 \sigma(I)$ $R_{\text {int }}=0.053$
Table 1

Hydrogen-bond geometry $\left(\AA,^{\circ}\right)$ for (I).

Symmetry codes: (i) $-x,-y,-z+1$; (ii) $x+\frac{1}{2},-y+\frac{1}{2},-z+1$; (iii) $x-\frac{1}{2}, y,-z+\frac{1}{2}$; (iv) $-x+\frac{1}{2}, y+\frac{1}{2}, z ;$ (v) $x+\frac{1}{2}, y,-z+\frac{1}{2}$; (vi) $-x-\frac{1}{2}, y+\frac{1}{2}, z$.

Table 2

Hydrogen-bond geometry $\left(\AA,^{\circ}\right)$ for (II).

\begin{tabular}{lllll}
\hline$D-\mathrm{H} \cdots A$ & $D-\mathrm{H}$ & $\mathrm{H} \cdots A$ & $D \cdots A$ & $D-\mathrm{H} \cdots A$ \\
\hline $\mathrm{O} 1-\mathrm{H} 1 B \cdots \mathrm{O} 11$ & $0.836(11)$ & $2.277(13)$ & $2.7107(7)$ & $112.7(11)$ \\
$\mathrm{O} 1-\mathrm{H} 1 A \cdots \mathrm{O} 12$ & $0.815(11)$ & $1.982(11)$ & $2.7929(8)$ & $173.4(13)$ \\
$\mathrm{O} 1-\mathrm{H} 1 B \cdots \mathrm{O} 14$ & $0.836(11)$ & $2.066(12)$ & $2.8929(8)$ & $170.2(13)$ \\
$\mathrm{O} 2-\mathrm{H} 2 A \cdots 4^{\mathrm{i}}$ & $0.847(12)$ & $2.131(12)$ & $2.9510(8)$ & $162.9(13)$ \\
$\mathrm{O} 2-\mathrm{H} 2 B \cdots \mathrm{O} 13^{\text {ii }}$ & $0.836(11)$ & $1.991(12)$ & $2.8048(8)$ & $164.2(13)$ \\
$\mathrm{O} 3-\mathrm{H} 3 A \cdots \mathrm{O} 13^{\text {iii }}$ & $0.816(11)$ & $2.032(11)$ & $2.8290(8)$ & $165.2(13)$ \\
$\mathrm{O} 3-\mathrm{H} 3 B \cdots \mathrm{O} 14^{\text {iv }}$ & $0.820(11)$ & $2.024(11)$ & $2.8409(8)$ & $174.9(13)$ \\
$\mathrm{O} 4-\mathrm{H} 4 A \cdots \mathrm{O} 15^{\mathrm{v}}$ & $0.842(11)$ & $1.835(11)$ & $2.6766(8)$ & $177.1(13)$ \\
$\mathrm{O} 4-\mathrm{H} 4 B \cdots \mathrm{O} 12^{\text {ii }}$ & $0.835(11)$ & $1.872(11)$ & $2.6885(8)$ & $165.8(13)$ \\
$\mathrm{O} 5-\mathrm{H} 5 B \cdots \mathrm{O} 13^{\text {vi }}$ & $0.824(11)$ & $1.911(11)$ & $2.7325(8)$ & $175.1(13)$ \\
$\mathrm{O}^{\mathrm{O}}-\mathrm{H} 5 A \cdots \mathrm{O} 14^{\mathrm{v}}$ & $0.831(11)$ & $1.974(11)$ & $2.7997(8)$ & $172.7(13)$ \\
$\mathrm{O}^{\mathrm{O}}-\mathrm{H} 6 A \cdots \mathrm{O} 12^{\text {ii }}$ & $0.831(11)$ & $2.065(12)$ & $2.8105(8)$ & $149.1(12)$ \\
$\mathrm{O}^{\mathrm{O}}-\mathrm{H} 6 B \cdots \mathrm{O} 15^{\text {iv }}$ & $0.841(11)$ & $1.909(11)$ & $2.7435(8)$ & $172.0(13)$ \\
\hline
\end{tabular}

Symmetry codes: (i) $-x,-y+1,-z+1$; (ii) $-x+1,-y+1,-z+1$; (iii) $x-1, y$, $z-1$; (iv) $x,-y+\frac{1}{2}, z-\frac{1}{2}$; (v) $x,-y+\frac{1}{2}, z+\frac{1}{2}$; (vi) $x-1, y, z$.

The $\mathrm{H}$ atoms of the FDA anions were included in idealized positions and refined as riding, with $\mathrm{C}-\mathrm{H}=0.95 \AA$ and $U_{\text {iso }}(\mathrm{H})=$ $1.2 U_{\text {eq }}(\mathrm{C})$. The $\mathrm{H}$ atoms of the water molecules were located in a Fourier map and their positions were refined with $\mathrm{O}-\mathrm{H}$ distances restrained to $0.85(2) \AA$, and with $U_{\text {iso }}(\mathrm{H})=1.2 U_{\text {eq }}(\mathrm{O})$.

For both compounds, data collection: COLLECT (Nonius, 1999); cell refinement: COLLECT; data reduction: EVALCCD (Duisenberg et al., 2003); program(s) used to solve structure: SHELXS97 (Sheldrick, 2008); program(s) used to refine structure: SHELXL97 (Sheldrick, 2008); molecular graphics: ORTEP-3 (Farrugia, 1997); software used to prepare material for publication: SHELXL97 and OLEX2 (Dolomanov et al., 2009).

Supplementary data for this paper are available from the IUCr electronic archives (Reference: BI3023). Services for accessing these data are described at the back of the journal.

\section{References}

Allen, F. H. (2002). Acta Cryst. B58, 380-388.

Boisen, A., Christensen, T. B., Fu, W., Gorbanev, Y. Y., Hansen, T. S., Jensen, J. S., Klitgaard, S. K., Pedersen, S., Riisager, A., Ståhlberg, T. \& Woodley, J. M. (2009). Chem. Eng. Res. Des. 87, 1318-1327.

Bozell, J. J. \& Petersen, G. R. (2010). Green Chem. 12, 539-554.

Coppens, P. (1970). Crystallographic Computing, edited by F. R. Ahmed, S. R. Hall \& C. P. Huber, pp. 255-270. Copenhagen: Munksgaard. 


\section{metal-organic compounds}

Dolomanov, O. V., Bourhis, L. J., Gildea, R. J., Howard, J. A. K. \& Puschmann, H. (2009). J. Appl. Cryst. 42, 339-341.

Duisenberg, A. J. M., Kroon-Batenburg, L. M. J. \& Schreurs, A. M. M. (2003). J. Appl. Cryst. 36, 220-229.

Farrugia, L. J. (1997). J. Appl. Cryst. 30, 565.

Gorbanev, Y. Y., Kegnæs, S. \& Riisager, A. (2011). Top. Catal. doi:10.1007/ s11244-011-9754-2.

Gorbanev, Y. Y., Klitgaard, S. K., Woodley, J. M., Christensen, C. H. \& Riisager, A. (2009). ChemSusChem, 2, 672-675.

Jaulmes, S., Cassanas, G. \& Laruelle, P. (1982). Acta Cryst. B38, 279-281.
Jeffrey, G. A. (1997). An Introduction to Hydrogen Bonding. Oxford University Press.

Martuscelli, E. \& Pedone, C. (1968). Acta Cryst. B24, 175-179.

Nonius (1999). COLLECT. Nonius BV, Delft, The Netherlands.

Paluchowska, B., Lis, T. \& Leciejewicz, J. (1994). Acta Cryst. C50, 683-686.

Sheldrick, G. M. (2008). Acta Cryst. A64, 112-122.

Werpy, T. \& Petersen, G. (2004). Top value added chemicals from biomass. US Department of Energy, Office of Scientific and Technical Information, No. DOE/GO-102004-1992, http://www.nrel.gov/docs/fy04osti/ 35523.pdf. 